\section{IN ROME COUNCIL DECIDED}

- To raise the unit fee from $7 \mathrm{SwFr}$ to 8 SwFr from 1 January 1980 (by a large majority).

To lower the unit rating of $4 \mathrm{~A}$ Members from 16 units to 14 units (by a large majority after an amendment to go to 12 units was narrowly defeated).

To launch the EPS Lecturer Exchange Scheme immediately with a view to arranging for several lecturers to be in post in the Autumn of 1980.

- To change the Constitution by amending Article 19 to read as was proposed in the Dec. 1978 issue of Europhysics News, p. 12.

\section{Report Next Month}

\section{EPS Executive Committee}

Council in Rome elected as EPS Executive Committee for 1979 :

$\begin{array}{ll}\text { President: } & \text { A. Zichichi } \\ \text { Vice-President : } & \text { S. Kapitza } \\ \text { Secretary : } & \text { L.A. Thomas } \\ \text { Vice-Secretary : } & \text { E.A. Müller } \\ \text { Treasurer : } & \text { A.R. Mackintosh } \\ \text { Vice-Treasurer : } & \text { P. Radvanyi } \\ \text { Members : } & \text { H. de Waard } \\ & \text { A. Lösche } \\ & \text { W. Martienssen } \\ & \text { A. Milojevic } \\ & \text { Z. Wilhelmi }\end{array}$

\section{I.O.M. DELEGATE}

The new I.O.M. delegate in place of the retiring delegate, H.A. Olsen of Trondheim, following the recent postal elections is David Blackburn, Director of the Open University's Research Unit at Oxford, UK. His election statement read "I want to strengthen the EPS activities in science, society and education: effective systems for career-long education of physicists; education of non physicists on the scientific and technological aspects of decision making in society". First alternate is Daniel Massignon of Paris.

EPS Divisions, Sections and Group

Astronomy and Astrophysics Division Solar Section

Atomic Physics Division

Atomic Spectroscopy Section

Atomic Spectroscopy

Chemical Physics
Electronic and Atomic Collisions

Molecular Physics

Computational Physics Group

Condensed Matter Division

Low Temperature Section

Macromolecular Physics

Magnetism

Metals

Semiconductors and Insulators

Surface and Interface

High Energy \& Particle Physics Division

Nuclear Physics Division

Plasma Physics Division

Quantum Electronics Division

\title{
WANTED
}

\section{INNOVATORS IN PHYSICS TEACHING EXCEPTIONAL TEACHERS OF PHYSICS}

\author{
to participate in the newly-launched \\ EPS Lecturer Exchange Scheme
}

The Scheme is designed to encourage the growth of excellence in physics teaching by the cross-fertilization of methods and the international exchange of top-grade exponents. University teachers should now consider whether they qualify themselves or whether they can recommend others who should participate. Proposals can be made to the EPS Secretariat from now on. Further details will be published in the May issue of Europhysics News.

\section{EPS Scholarships: Third List}

\section{FEDERAL REPUBLIC OF GERMANY ITALY}

\section{Karlsruhe}

Note that the salary quoted for the Karlsruhe scholarships is a net figure with all taxes deducted.

\section{GSI}

The Gesellschaft für Schwerionenforschung is the principal national heavy ion physics laboratory.

For scholars, principal contact will be through the office of the scientific director, Professor Dr. G. zu Putlitz. Scholarships, initially for a period of one year are for post-doctoral research in :

1) Nuclear reactions, heavy ion nuclear physics

2) Heavy ion nuclear chemistry

3) Heavy-ion atomic physics

4) Applied research with heavy ions, in particular in biophysics

5) Data handling and data acquisition. Salary will be between 2500 and $3500 \mathrm{DM} / \mathrm{month}$ depending on experience and responsibilities. Normal travel costs will be paid.

\section{Kernforschungsanlage (KFA), Jülich}

Details will be published later of the scholarship that KFA is making available to EPS.

Europhysics News is the official journal of the European Physical Society that comprises $28 \mathrm{Na}$ tional Societies, Academies and Groups, ove 3000 Individual Ordinary Members and 30 Associate Members. Governing bodies of EPS are the General Meeting. Council and an elected ExecGeneral Meeting. Council and an elected ExecEPS promotes the collaboration of physicists throughout Europe and encourages all aspects of international exchange in physics. EPS awards scholarships for research and studies in differen countries. EPS publishes, in addition to Europhys ics News, Europhysics Conference Abstracts, Europhysics Education News and the Proceedings of ts General Conferences. Individual Ordinan Members receive Europhysics News (subscription for non-Members: $75 \mathrm{Sw}$. Fr./a), substantial rebates on many publications and pay reduced fees at conferences. Application for membership is made through the permanent Secretariat which is located in Geneva. Annual subscription fo members of a National Society is $28 \mathrm{Sw} . \mathrm{Fr}$.
INFN, the Italian national institute for research in nuclear physics is, for the 1979-1980 year, once again offering eight scholarships. Each scholarship is valid for nine months starting on 1 Oct. Salary will be 500000 Italian Lire/month net.

INFN sections able to receive scholars are established in the institutes of physics at the Universities of : Bari, Bologna, Catania, Florence, Genoa, Milan, Naples, Padua, Pavia, Pisa, Rome, Trieste and Turin.

In addition scholarships are applicable to the INFN sections at the :

Istituto Superiore Sanità of Rome, to the national laboratory of Frascati and the national laboratory of Legnaro, Padua.

Relevant fields of interest are nuclear and sub-nuclear physics, both theoretical and experimental.

Applications to the EPS Secretariat before 1 July, 1979.

\section{EPS Scholarships Previous Lists}

For lists 1 and 2 that apply to scholastic year 1979/80 consult the December (1978) and Jan/Feb issues of Europhysics News.

Editor: E.N. Shaw

Meetings Compllation: W.S. Newman

Editorial Board

G.J. Béné, G.R. Macleod, A. Maeder,

J. Muller, D. Pohl

Editorial and Advertising Office at the EPS Secretariat.

Address: EUROPEAN PHYSICAL SOCIETY P.O. Box 69, CH-1213 Petit-Lancy 2 Switzerland

Telephone: Geneva (22) 931130

Telex: 23455 alarm ch

Cables: europhys genève

Printed by : Ed. Cherix et Fllanosa SA CH-1260 Nyon, Switzerland 